\title{
Peningkatan Kemampuan Representasi Matematis Siswa Kelas X2 SMAN 1 Gedung Meneng Menggunakan Bahan Ajar Matriks Berbasis Pendekatan Saintifik
}

\author{
Siti Ramziah \\ SMAN 1 Banjar Margo \\ e-mail: rati_sitiramziah@yahoo.co.id
}

\begin{abstract}
ABSTRAK
Penelitian ini bertujuan untuk meningkatkan aktivitas dan kemampuan representasi matematis siswa kelas $\mathrm{X}_{2}$ SMA Negeri 1 Gedung Meneng dalam menggunakan bahan ajar matriks yang dikembangkan dengan pendekatan saintifik. Penelitian menggunakan metode classroomaction research atau penelitian tindakan kelas yang memiliki desain yang berupa daur spiral dengan empat langkah utama yaitu: perencanaan, tindakan, pengamatan dan refleksi. Pengumpulan data pada penelitian ini menggunakan observasi dan tes. Semua data yang dikumpulkan kemudian dianalisis dan dapat disimpulkan bahwa bahan ajar matriks yang dikembangkan menggunakan pendekatan saintifik dapat meningkatkan aktivitas siswa yang dapat dilihat dari besarnya peningkatan aktivitas siswa tersebut sebesar 9,9\%.Bahan ajar matriks yang dikembangkan menggunakan pendekatan saintifik dapat meningkatkan kemampuan representasi matematis siswa yang dapat dilihat dari besarnya peningkatan kemampuan tersebut sebesar $8,15 \%$ yang diiringi juga dengan meningkatnya hasil belajar siswa secara klasikal sebesar 10,3\%.
\end{abstract}

\section{Kata kunci: Bahan Ajar, Pendekatan Saintifik, Kemampuan Representasi Matematis}

\begin{abstract}
This study aims to improve the activity and the ability of the mathematical representation $\mathrm{X}_{2}$ grade students of SMA Negeri 1 Gedung Meneng in using teaching materials matrix developed by scientific approach. Research method iss classroom action research or action research that has a design in the form of a spiral cycle with four main steps: planning, action, observation and reflection. Collecting data in this study used observation and tests. All data collected was analyzed and concluded that the teaching material matrix developed using a scientific approach could increase the activity of students. It could be seen from the increasing in the student activity by $9.9 \%$. Teaching materials matrix developed using a scientific approach could improve students' mathematical representation that could be seen from the large increasing in the ability of $8.15 \%$ which accompanied by increasing student learning outcomes in classical amount to $10.3 \%$.
\end{abstract}

Keywords: Subjects, Scientific Approach, Mathematical Representation Ability.

\section{PENDAHULUAN}

Pembelajaran matematika terkait Kurikulum 2013 adalah pembelajaran kompetensi matematis dengan memperkuat proses pembelajaran dan penilaian autentik untuk mencapai kompetensi pengetahuan, sikap, dan keterampilan. Penguatan proses pembelajaran Kurikulum 2013 dilakukan melalui pendekatan saintifik. Menurut Permendikbud Nomor 81 A Tahun 2013 Lampiran IV menyatakan bahwa proses pembelajaran menggunakan pendekatan saintifik atau ilmiah terdiri atas lima pengalaman belajar pokok yang meliputi mengamati, menanya, mengumpulkan informasi, mengasosiasi, dan mengkomunikasikan.

Kelima pengalaman belajar tersebut harus dibelajarkan kepada peserta didik melalui model-model pembelajaran yang disesuaikan dengan materi matematika. Selain itu, Permendiknas RI Nomor 41 (2007) juga mengatakan bahwa proses pembelajaran pada setiap satuan pendidikan dasar dan menengah harus interaktif, inspiratif, menyenangkan, menantang, dan memotivasi siswa untuk 
berpartisipasi aktif, serta memberikan ruang yang cukup bagi prakarsa, kreativitas, dan kemandirian sesuai dengan bakat, minat, dan perkembangan fisik serta psikologis siswa. Oleh karena itu, guru harus mampu mendesain pembelajaran matematika dengan metode, pendekatan dan model pembelajaran yang mampu membelajarkan siswa sebagai subjek belajar dan bukan sebagai objek belajar. Hal ini bertujuan agar efek dari pembelajaran matematika tersebut akan menjadikan siswa memiliki kemampuankemampuan matematis.

Berdasarkan uraian di atas perlu adanya upaya untuk mengembangkan kemampuankemampuan matematis pada diri siswa dalam pembelajaran matematika. Kemampuan matematis yang perlu dikembangkan diantaranya adalah kemampuan representasi matematis. Dalam National Council of Teachers of Mathematics (NCTM) tahun 2000 disebutkan bahwa kemampuan pemahaman dan representasi matematis merupakan aspek yang sangat penting dalam prinsip pembelajaran matematika. Siswa dalam belajar matematika harus disertai dengan pemahaman, hal ini merupakan tujuan dari belajar matematika. Siswa dapat mengembangkan dan memahami konsep matematis lebih dalam, dengan menggunakan representasi yang bermacam-macam. Kemampuan representasi yang digunakan dalam belajar matematika seperti objek fisik, menggambar, grafik, dan simbol, akan membantu komunikasi dan berpikir siswa. Lebih lanjut Sumarmo (dalam Tandililing, 2011) juga menyatakan bahwa pembelajaran matematika perlu diarahkan untuk pemahaman konsep dan prinsip matematika yang kemudian diperlukan untuk menyelesaikan masalah matematika, masalah dalam disiplin ilmu lain, dan masalah dalam kehidupan sehari-hari. Senada dengan pernyataan Sumarmo, Anderson at Al (dalam Tandililing, 2011) mengungkapkan bahwa pemahaman terhadap suatu masalah merupakan bagian dari pemecahan masalah. Dengan demikian dapat disimpulkan bahwa representasi matematis merupakan bantuan dalam memahami konsep dan prinsip matematika secara mendalam guna penyederhanaan penyelesaian masalah matematika.

Dalam upaya peningkatan kemampuankemampuan matematis siswa seperti yang dipaparkan di atas, beberapa ahli mengungkapkan hal lain yang dapat membantu proses pembelajaran dalam pencapaian tujuan pembelajaran matematika seperti yang diungkapkan oleh Pitadjeng (2005) yang mengatakan bahwa agar murid dapat belajar matematika dalam suasana yang menyenangkan guru harus mengupayakan adanya situasi dan kondisi yang menyenangkan, strategi yang menyenangkan, maupun materi matematika yang menyenangkan. Lebih lanjut Pitadjeng (2005) memberi kesan matematika tidak sulit dapat dilakukan antara lain dengan memberikan masalah kontekstual, tingkat kesulitan masalah sesuai atau lebih sedikit dari tingkat kemampuan anak dan peningkatan kesulitan masalah sedikit demi sedikit. Dengan demikian pembelajaran matematika akan menarik dan menjadi bermakna bagi siswa jika diawali dari sesuatu yang nyata dan sesuai dengan pengalaman siswa. Seperti halnya pembelajaran matriks di kelas X, dapat diawali dengan pemberian masalah di kehidupan sehari-hari yang dekat dengan kehidupan siswa misalnya dengan penyajian data dalam bentuk tabel dan kepramukaan.

Berdasarkan pengalaman peneliti dan guru matematika lain, selama membelajarkan materi matriks dengan menggunakan metode konvensional, hasil belajar siswa cukup memuaskan yang dapat dilihat dari hasil ulangan harian sebagian besar telah mencapai Kriteria Ketuntasan Minimal (KKM). Akan tetapi, ketika siswa dihadapkan pada soal yang mengarah pada soal cerita di kehidupan sehari-hari, kenyataannya sebagian besar 
siswa bingung dan sulit dalam merepresentasikan masalah di kehidupan sehari-hari ke bentuk matriks dan hal ini berakibat pada sulitnya siswa dalam menyelesaikan masalah sehari-hari dengan mengaplikasikan materi matriks yang telah dipelajari. Hal ini dikarenakan peneliti menyadari bahwa pembelajaran matriks yang selama ini dilakukan hanya sebatas prosedural yaitu menerapkan aturan atau rumus yang ada dalam penyelesaian soal dan siswa belum pernah diajak untuk mengaitkan masalah sehari-hari dalam representasi matriks. Selain kurang terampil merepresentasikan masalah kehidupan sehari-hari ke dalam bentuk matriks, siswa juga belum begitu dominan dalam mengkomunikasikan pendapat, ide, atau gagasan baik secara tertulis maupun secara lisan. Namun, sejauh penerapan Kurikulum 2013 diterapkan di SMA Negeri 1 Gedung Meneng pada tahun 2014, peneliti telah mencoba untuk membelajarkan siswa menggunakan bahan ajar yang peneliti kembangkan sendiri untuk materi pangkat, bentuk akar, logaritma, sistem persamaan linier, dan nilai mutlak. Bahan ajar yang dikembangkan oleh peneliti untuk materi tersebut sejauh ini membantu siswa dalam memahami buku siswa yang digunakan sesuai dengan tuntutan kurikulum.

Oleh sebab itu, berdasarkan uraian di atas, peneliti tertarik untuk meneliti tentang "Peningkatan Kemampuan Representasi Matematis Siswa Kelas $\mathrm{X}_{2}$ SMAN 1 Gedung Meneng Menggunakan Bahan Ajar Matriks Berbasis Pendekatan Saintifik", dengan harapan siswa menjadi lebih tertarik dan banyak aktivitas yang dilakukan dalam pembelajaran matriks, terampil dalam merepresentasikan matriks serta mengaplikasikannya dari masalah di kehidupan sehari-hari. Adapun tujuan dari penelitian ini adalah untuk meningkatkan aktivitas siswa kelas $X_{2}$ SMA Negeri 1 Gedung Meneng dalam menggunakan bahan ajar matriks yang dikembangkan dengan pendekatan saintifik dan untuk meningkatkan kemampuan representasi matematis siswa kelas $\mathrm{X}_{2}$ SMA Negeri 1 Gedung Meneng setelah menggunakan menggunakan bahan ajar matriks yang dikembangkan dengan pendekatan saintifik.

\section{METODE}

Subjek penelitian ini adalah siswa kelas $\mathrm{X}_{2} \quad$ SMA Negeri 1 Gedung Meneng Kabupaten Tulang Bawang Lampung yang dilaksanakan pada bulan NovemberDesember 2014. Adapun jumlah siswa di kelas ini adalah 29 orang dan dalam praktiknya siswa dibagi menjadi beberapa kelompok yang beranggotakan 4-5 orang dengan kemampuan yang berbeda di setiap kelompoknya.Adapun metode yang peneliti gunakan dalam penelitian ini adalah metode classroomaction research atau penelitian tindakan kelas.

Penelitian tindakan memiliki desain yang berupa daur spiral Suhardjono (2006) dengan empat langkah utama yaitu: perencanaan, tindakan, pengamatan dan refleksi. Berdasarkan desain penelitian tersebut dapat dikatakan bahwa penelitian tindakan merupakan proses perbaikan secara terus menerus dari suatu tindakan yang masih mengandung kelemahan sebagaimana hasil refleksi yang menuju ke arah yang semakin sempurna.

Adapun penjelasan secara rinci dari tahapan pada daur spiral sebagai berikut:

\section{Permasalahan}

Pada tahapan ini, peneliti mencari informasi untuk mengenali dan mengetahui kesulitan belajar siswa kelas $\mathrm{X}_{2}$ SMA Negeri 1 Gedung Meneng pada materi matriks.

\section{Perencanaan Tindakan Siklus I}

Pada tahap ini, penelitimelakukan analisis kurikulum untuk mengetahui kompetensi dasar yang hendak dimiliki siswa. Adapun kegiatan yang peneliti lakukan sebagai berikut: 
a. Mempersiapkan LAS yang dikembangkan dengan menggunakan pendekatan saintifik.

b. Mempersiapkan alat evaluasi pembelajaran (tes).

c. Mempersiapkan lembar observasi aktivitas siswa.

d. Mempersiapkan rencana pembelajaran berupa RPP yang secara umum dengan alur sebagai berikut:

- Memberikan permasalahan yang disajikan pada LAS.

- Siswa berdiskusi untuk memahami dan mencari solusi dari permasalahan yang disajikan pada LAS (dilakukan dengan tahapan yang

meliputi mengamati, menanya, me ngumpulkan informasi, mengasosi asi, dan mengkomunikasikan).

- Siswa mempresentasikan hasil diskusi kelompoknya dan terdapat diskusi kelas untuk mencari suatu kesimpulan.

- Sebagai penguatan dari materi yang telah dipelajari, siswa diminta untuk menyelesaikan permasalahan pada latihan soal secara individu.

3. Pelaksanaan Tindakan Siklus I

Melaksanakan kegiatan pembelajaran sesuai dengan rencana yang telah disiapkan.

4. Pengamatan/Pengumpulan Data Siklus I

Kegiatan ini dilakukan bersamaan dengan pelaksanaan tindakan. Data yang dikumpulkan pada tahap ini berisi tentang pelaksanaan tindakan dan rencana yang sudah dibuat serta dampaknya terhadap proses dan hasil instruksional yang dikumpulkan dengan alat bantu lembar pengamatan.

\section{Refleksi Siklus I}

Hasil yang diperoleh dalam tahap pengamatan dikumpulkan serta dianalisis. Dari hasil analisis, peneliti dapat merefleksi diri, apakah kegiatan yang telah dilakukan sudah ada peningkatan, dan dimana kekurangan yang harus diperbaiki.

\section{Revisi Tindakan Siklus I}

Dari hasil refleksi siklus I dilakukan perencanaan tindakan siklus II, Pelaksanaan tindakan silkus II, pengamatan/pengumpulan data siklus II, refleksi siklus II dan seterusnya sampai skenario pembelajaran dapat diselesaikan.

\section{Teknik Pengumpulan Data}

Teknik pengumpulan data yang digunakan dalam penelitian ini adalah:

1. Observasi terhadap aktivitas

Data tentang keaktifan belajar siswa diambil dengan lembar observasi dan dibantu oleh 2 observer. Pada penelitian ini keaktifan dinilai berdasarkan indikatorindikator yang telah ditetapkan berupa kelima pengalaman belajar dalam pendekatan saintifik yaitu mengamaati, menanya, mengumpulkan informasi, mengasosiasi, dan mengkomunikasikan.

\section{Tes}

Tes yang digunakan adalah tes tertulis bentuk uraian pada setiap akhir siklus. Tes ini digunakan untuk mengukur hasil belajar siswa dalam ranah kognitif.

\section{Teknik Analisis Data}

\section{Analisis Observasi}

Data yang diperoleh dalam penelitian ini berupa data kualitatif yang diperoleh dari hasil observasi tehadap siswa selama proses pembelajaran dalam pengerjaaan LAS yang telah dikembangkan, kemudian dianalisis setiap akhir pertemuan di setiap siklus.

\section{Analisis Tes}

Data yang diperoleh dari lembar jawaban siswa dalam menyelesaikan soalsoal pada tes yang dilaksanakan di setiap akhir suatu siklus.Analisis data tes dilakukan untuk mengetahui kemampuan representasi matematis siswa dalam menyelesaikan soal-soal yang memuat 
indikator kemampuan representasi matematis dengan tujuan untuk melihat pemahaman dan penguasaan materi matriks, setelah penggunaan LAS yang telah dikembangkan berdasarkan pendekatan saintifik sehingga diperoleh tingkat keberhasilan atau kualitas hasil belajar.

Skor yang diperoleh siswa dari hasil tes dikonversi dari rentang 0 sampai dengan 100 dengan rumus:

$$
N=\frac{x_{1}}{n} x 100
$$

(Rohani, 2004)

Keterangan:

$\mathrm{N} \quad=$ Nilai

$x_{1}=$ Skor yang diperoleh siswa

$\mathrm{n} \quad=$ Skor maksimum

Hasil belajar siswa dikelompokkan menjadi dua kategori berdasarkan KKM yang telah ditentukan $(\mathrm{KKM}=67)$, yaitu tuntas dan tidak tuntas. Proses pembelajaran dikatakan tuntas secara klasikal apabila hasil belajar siswa yang tuntas minimal telah mencapai $85 \%$.

\section{HASIL DAN PEMBAHASAN Hasil Penelitian}

Penelitian ini menghasilkan peningkatan kemampuan representasi matematis dan aktivitas siswa kelas $\mathrm{X}$ SMA Negeri 1 Gedung Meneng dengan menggunakan bahan ajar yang dikembangkan menggunakan pendekatan saintifik. Pelaksanaan pembelajaran dalam penelitian ini dilakukan sebanyak 2 siklus yang masing-masing siklus pembelajaran dilakukan sebanyak 4 kali pertemuan yaitu 3 kali pertemuan untuk proses pembelajaran dan 1 kali pertemuan untuk tes hasil belajar. Setiap pelaksanaan pembelajaran dimulai dengan pemberian LAS yang menyajikan berbagai masalah di kehidupan sehari-hari.
Padasiklus pertama dilakukan sebanyak 4 kali pertemuan dengan materi pada pertemuan pertama adalah definisi matriks, pertemuan kedua adalah ordo matriks, dan pertemuan ketiga adalah transpose dan kesamaan dua matriks. Selanjutnya pertemuan keempat dilakukan tes hasil belajar. Adapun kompetensi dasar dan indikator pembelajaran sebagai berikut:

Kompetensi Dasar:

3.4 Mendeskripsikan konsep matriks sebagai representasi numerik dalam kaitannya dengan konteks nyata.

4.6 Menyajikan model matematika dari suatu masalah nyata yang berkaitan dengan matriks.

Indikator:

1. Merepresentasi masalah nyata di kehidupan sehari-hari dalam bentuk matriks

2. Menentukan elemen anggota pada baris dan kolom yang terdapat pada sebuah matriks

3. Menentukan ordo sebuah matriks

4. Menentukan transpose dari sebuah matriks dari masalah nyata kehidupan sehari-hari

5. Menentukan elemen anggota matriks dari kesamaan dua matriks yang direpresentasikan dari masalah nyyata kehidupan sehari-hari.

Pada siklus kedua dilakukan sebanyak 4 kali pertemuan dengan materi pada pertemuan pertama adalah penjumlahan dan pengurangan dua buah matriks atau lebih. Pada pertemuan kedua dan ketiga, materi yang diajarkan adalah perkalian matriks. Selanjutnya pertemuan keempat dilakukan tes hasil belajar. Adapun kompetensi dasar dan indikator pembelajaran sebagai berikut:

Kompetensi Dasar:

3.5 Mendeskripsikan operasi sederhana matriks serta menerapkannya dalam pemecahan masalah. 
4.6 Menyajikan model matematika dari suatu masalah nyata yang berkaitan dengan matriks.

Indikator:

1. Menggunakan operasi penjumlahan matriks dari masalah nyata kehidupan sehari-hari

2. Menggunakan operasi pengurangan matriks dari masalah nyata kehidupan sehari-hari

3. Menggunakan operasi perkalian matriks yang direpresentasikan dari masalah nyata di kehidupan seharihari
Pada akhir tiap siklus diadakan tes guna mengetahui hasil belajar siswa dalam menyelesaikan permasalahan untuk mengukur kemampuan representasi matematis. Adapun tahapan yang dilakukan pada setiap siklus dalam penelitian ini menggunakan daur spiral dengan tahapan yang meliputi permasalahan, perencanaan, pelaksanaan, pengamatan/pengumpulan data, dan refleksi, dan seterusnya sampai skenario pembelajaran dapat diselesaikan. Kemampuan representasi matematis siswa yang dicapai pada siklus I dan siklus II disajikan pada tabel 1 dan 2 berikut:

Tabel 1. Persentase Kemampuan Representasi pada Siklus I

\begin{tabular}{|c|c|c|c|}
\hline $\begin{array}{l}\text { No } \\
\text { Soal }\end{array}$ & Indikator & $\begin{array}{c}\text { Jumlah } \\
\text { Siswa }\end{array}$ & $\%$ \\
\hline 1 & $\begin{array}{l}\text { 1. Menyajikan kembali data atau informasi ke dalam bentuk tabel. } \\
\text { 2. Menggunakan representasi visual untuk menyelesaikan masalah. }\end{array}$ & $\begin{array}{l}29 \\
29\end{array}$ & $\begin{array}{l}100 \% \\
100 \%\end{array}$ \\
\hline \multicolumn{3}{|c|}{ Rata-rata } & $100 \%$ \\
\hline 2 & $\begin{array}{l}\text { 1. Menggunakan representasi visual untuk menyelesaikan } \\
\text { permasalahan/soal. } \\
\text { 2. Menjawab soal dengan menggunakan kata-kata atau teks tertulis. }\end{array}$ & 29 & $100 \%$ \\
\hline \multicolumn{3}{|c|}{ Rata-rata } & $\mathbf{1 0 0 \%}$ \\
\hline 3 & $\begin{array}{l}\text { 1. Menggunakan representasi visual untuk menyelesaikan } \\
\text { permasalahan/soal. } \\
\text { 2. Menjawab soal dengan menggunakan kata-kata atau teks tertulis. }\end{array}$ & 29 & $100 \%$ \\
\hline \multicolumn{3}{|c|}{ Rata-rata } & $55,2 \%$ \\
\hline 4 & $\begin{array}{l}\text { 1. Menyajikan informasi ke dalam bentuk tabel atau gambar } \\
\text { 2. Menggunakan representasi visual untuk menyelesaikan } \\
\text { permasalahan/soal } \\
\text { 3. Menjawab soal dengan menggunakan kata-kata atau teks tertulis. }\end{array}$ & $\begin{array}{l}22 \\
22 \\
3\end{array}$ & $\begin{array}{l}75,9 \% \\
75,9 \% \\
10,3 \%\end{array}$ \\
\hline \multicolumn{3}{|c|}{ Rata-rata } & $54 \%$ \\
\hline & Rata-rata Kemampuan Representasi Matematis pada Siklus I & & $\mathbf{7 7 , 3 \%}$ \\
\hline
\end{tabular}

Tabel 2. Persentase Kemampuan Representasi pada Siklus II

\begin{tabular}{|c|c|c|c|}
\hline $\begin{array}{c}\text { No } \\
\text { Soal }\end{array}$ & \multicolumn{1}{c|}{ Indikator } & $\begin{array}{c}\text { Jumlah } \\
\text { Siswa }\end{array}$ & $\%$ \\
\hline $\mathbf{1}$ & 1. Menggunakan representasi visual untuk menyelesaikan masalah. & 29 & $100 \%$ \\
& 2. Menjawab soal dengan kata-kata atau teks tertulis. & 22 & $75,8 \%$ \\
\hline \multicolumn{2}{|c|}{ Rata-rata } & $\mathbf{8 7 , 9 \%}$ \\
\hline $\mathbf{2}$ & 1. Menyajikan informasi ke dalam bentuk tabel. & 29 & $100 \%$ \\
& 2. Menggunakan representasi visual untuk menyelesaikan masalah. & 29 & $100 \%$ \\
& 3. Menjawab soal dengan kata-kata atau teks tertulis. & 20 & $68,9 \%$ \\
\hline \multicolumn{2}{|c|}{ Rata-rata } & 29 & $100 \%$ \\
\hline $\mathbf{3}$ & 1. Menyajikan informasi ke dalam bentuk tabel. & 29 & $100 \%$ \\
& 2. Menggunakan representasi visual untuk menyelesaikan masalah. & 20 & $68,9 \%$ \\
\hline & 3. Menjawab soal dengan kata-kata atau teks tertulis. & $\mathbf{8 9 , 6 \%}$ \\
\hline $\mathbf{4}$ & Rata-rata & 23 & $79,3 \%$ \\
\hline
\end{tabular}




\begin{tabular}{|c|c|c|}
\hline $\begin{array}{l}\text { 2. Menggunakan representasi visual untuk menyelesaikan masalah. } \\
\text { 3. Menjawab soal dengan kata-kata atau teks tertulis. }\end{array}$ & $\begin{array}{l}23 \\
19\end{array}$ & $\begin{array}{c}79,3 \% \\
65,5\end{array}$ \\
\hline \multicolumn{2}{|l|}{ Rata-rata } & $74,7 \%$ \\
\hline Rata-rata Persentase Kemampuan Matematis & & $\mathbf{8 5 , 4 5 \%}$ \\
\hline
\end{tabular}

Selain itu, ketuntasan hasil belajar siswa klasikal dapat dilihat pada tabel 3 berikut:

Tabel 3. Rekapitulasi Hasil Tes dan Ketuntasan Klasikal pada Siklus I dan II

\begin{tabular}{|c|c|c|c|}
\hline Jumlah Siswa & $\begin{array}{c}\text { Siswa Yang Tuntas } \\
\text { Belajar }\end{array}$ & $\begin{array}{c}\text { Siswa Yang Tidak } \\
\text { Tuntas Belajar }\end{array}$ & $\begin{array}{c}\text { Ketuntasan } \\
\text { Klasikal }\end{array}$ \\
\hline 29 & 22 & 7 & $75,9 \%$ \\
\hline 29 & 25 & 4 & $86,2 \%$ \\
\hline
\end{tabular}

Selain kemampuan representasi persentase aktivitas siswa yang dapat dilihat matematis, penelitian ini juga menghasilkan pada tabel 4 berikut:

Tabel 4. Rekapitulasi Persentase Aktivitas Siswa pada Siklus I dan Siklus II

\begin{tabular}{|l|c|c|}
\hline \multicolumn{1}{|c|}{ Indikator Aktivitas } & I & II \\
\hline Siswa mengamati gambar, membaca permasalahan yang disajikan pada LAS & $95 \%$ & $100 \%$ \\
\hline Siswa bertanya terkait hal yang belum dipahami atau diyakini kebenarannya. & $88,7 \%$ & $94,5 \%$ \\
\hline $\begin{array}{l}\text { Siswa mengumpulkan informasi secara tertulis pada lembar yang telah disediakan } \\
\text { pada LAS dengan membaca referensi lain yang relevan }\end{array}$ & $86 \%$ & $94,5 \%$ \\
\hline Siswa mengolah informasi yang telah dikumpulkan & $87 \%$ & $94,5 \%$ \\
\hline Siswa mengkomunikasikan dari hasil diskusi kelompok yang telah dilakukan & $55 \%$ & $77,5 \%$ \\
\hline \multicolumn{1}{|c|}{ Rata-rata } & $\mathbf{8 2 , 3 \%}$ & $\mathbf{9 2 , 2 \%}$ \\
\hline
\end{tabular}

\section{Pembahasan}

Berdasarkan hasil pengamatan pelaksanaan tindakan pada siklus I, secara keseluruhan aktivitas siswa selama proses pembelajaran dengan menggunakan bahan ajar yang dikembangkan dengan pendekatan saintifik, siswa banyak melakukan aktivitas mengamati, menanya, mengumpulkan informasi, dan mengasosiasi. Akan tetapi, masih sedikit siswa yang turut berpatisipasi mengkomunikasikan hasil diskusi kelompok secara tertulis. Namun, pada kegiatan mengkomunikasikan di setiap pertemuan terjadi kenaikan meskipun sedikit. Siswa yang pada petemuan sebelumnya tidak ikut serta dalam menyumbangkan ide atau pendapat tetapi pada pertemuan berikutnya siswa tersebut sudah mulai berani dan turut berpartisipasi dalam mengkomunikasikan secara tertulis dari hasil diskusi kelompok.

Selain itu, berdasarkan hasil tes pada siklus I diperoleh bahwa kemampuan representasi matematis siswa sebesar $77,3 \%$ dimana lebih dari $80 \%$ siswa telah mampu menggunakan kemampuan representasi matemattis untuk indikator menyajikan informasi ke dalam bentuk tabel atau gambar, dan menggunakan representasi visual untuk menyelesaikan permasalahan/soal. Namun, hanya 10,3\% siswa yang memunculkan kemampuan representasi matematis dengan indikator menjawab soal dengan kata-kata atau teks tertulis. Kemudian, pada penyelesaian soal nomor 4 terdapat 22 siswa yang menyelesaikan soal nomor 4 yang diantaranya hanya 3 orang saja yang mampu melanjutkan kemampuan representasi matematis dengan indikator 
menjawab soal dengan kata-kata attau teks tertulis. Selain itu, terdapat 7 siswa yang tidak mampu menyelesaikan permasalahan/soal nomor 4. Hal inilah yang mengakibatkan hasil belajar ketujuh orang tersebut tidak dapat mencapai nilai KKM karena skor mentah yang diperoleh untuk keempat soal menjadi kecil.

Selanjutnya dari hasil pengamatan tindakan pada siklus II, secara keseluruhan proses pembelajaran dengan menerapkan bahan ajar yang dikembangkan menggunakan pendekatan saintifik terjadi peningkatan aktivitas siswa, terutama yang paling terlihat peningkatan pada aktivitas mengkomunikasikan. Besarnya peningkatan kegiatan mengkomunikasikan tersebut adalah 22,5\%. Hal ini terjadi karena dari hasil observasi peneliti dan observer, siswa telah terbiasa menyumbangkan ide, pendapat, dan saran untuk berdiskusi di dalam kelompoknya guna menarik kesimpulan sebagai hasil diskusi dengan menggunakan bahasa mereka sendiri.

Selain terjadi penigkatan dalam aktivitas siswa, dari hasil pengamatan siklus II, kemampuan representasi matematis. Sebagian besar siswa telah mampu menggunakan indikator kemampuan representasi matematis yaitu menyajikan informasi ke dalam bentuk tabel dan menggunakan representasi visual untuk menyelesaikan permasalahan/soal. Selain itu, untuk indikator kemampuan representasi matematis yakni menjawab soal dengan kata-kata atau teks tertulis teradi peningkatan pada siklus II yang dapat dilihat dari hasil jawaban siswa pada tes yang diberikan. Hal ini dapat dikatakan sebagai hasil dari penggunaan bahan ajar yang dikembangan menggunakan pedekatan saintifik dan bimbingan atau motivasi, sebagai refleksi dari siklus I. Secara keseluruhan kemampuan represntasi matematis siswa meningkat sebesar $8,15 \%$.

Berkaitan dengan meningkatnya kemampuan representasi matematis siswa, dapat juga dilihat relasi antara meningkatnya kemampuan representasi matematis denngan hasil belajar siswa. Besarnya peningkatan hasil belajar siswa tersebut merupakan dampak dari kemampuan representasi matematis yang telah dimanfaatkan oleh siswa guna membantu penyederhanaan terlebih lagi penyelesaian masalah yang diberikan. Adapun besarnya peningkatan ketuntasan belajar siswa secara klasikal adalah 10,1\%

Dengan demikian, ketuntasan belajar siswa pada siklus II secara klasikal telah mencapai 86,2\%. Hal ini dikarenakan siswa sudah mulai terbiasa dengan pembelajaran dengan enggunakan bahan ajar yang dikembangkan dengan pendekatan saintifik dan sudah mulai terbiasa dengan diskusi kelompok, sehingga mereka bisa saling berdiskusi dan berbagi pengetahuan dengan teman sekelompoknya dalam menyelesaikan masalah-masalah yang diberikan.

Sebagai hasil analisis data pada siklus I dan II dapat disimpulkan bahwa proses pembelajaran menjadi lebih baik, siswa berpartisipasi lebih aktif dalam proses pembelajaran dan mereka dapat mengungkapkan ide-ide mereka dalam berdiskusi. Hal ini dapat dilihat dari aktivitas siswa di setiap pertemuan yang semakin meningkat. Selain itu siswa sudah dapat menyelesaikan masalah-masalah di kehidupan sehari-hari dengan menyederhanakan permasalahan tersebut untuk dapat diselesaikan, denngan bantuan menggunakan kemampuan representasi matematis. Hampir semua siswa dapat merespon permasalahan yang diberikan dengan cara mereka sendiri dalam hal pembuatan tabel, dilanjutkan dengan penyelesaian secara lajabar dan teks 
tertulis, yang merupakan salah satu keunggulan dari menggunakan bahan ajar yang dikembangakan menggunakan pendekatan saintifik.

Dengan demikian dapat disimpulkan bahwa terjadi peningkatan hasil belajar dan aktivitas siswa dalam menyelesaikan masalah yang diberikan pada materi matriks adalah dengan meningkatkan kemampuan representasi matematis sebagai bantuan penyederhanan penyelesaian masalah yang diberikan serta dengan meningkatkan aktivitas siswa melalui kegiatan mengamati, bertanya, mengumpulkan informasi, mengasosiasi, dan mengkomunikasikan. Hal ini dapat dikatakan bahwa bahan ajar yang dikembangkan menggunakan pendekatan saintifik dapat meningkatkan aktivitas dan kemampuan represntasi matematis siswa.

\section{PENUTUP}

\section{Kesimpulan}

Berdasarkan hasil penelitian di SMA Negeri 1 Gedung Meneng pada Kelas $\mathrm{X}_{2}$ dapat disimpulkan bahwa:

1. Bahan ajar matriks yang dikembangkan menggunakan pendekatan saintifik dapat meningkatkan aktivitas siswa yang dapat dilihat dari besarnya peningkatan aktivitas siswa tersebut sebesar 9,9\%.

2. Bahan ajar matriks yang dikembangkan menggunakan pendekatan saintifik dapat meningkatkan kemampuan representasi matematis siswa yang dapat dilihat dari besarnya peningkatan kemampuan tersebut sebesar $8,15 \%$ yang diiringi juga dengan meningkatnya hasil belajar siswa secara klasikal sebesar $10,3 \%$.

\section{Saran}

Berdasarkan hasil penelitian, peneliti dapat menyarankan hal-hal berikut:

1. Bagi guru matematika

- Hasil dari pengembangan bahan ajar dengan pendekatan saintifik dapat digunakan oleh guru dalam proses pembelajaran untuk mencapai tujuan pembelajaran.

- Sebagai informasi bagi guru matematika dalam menentukan pendekatan pembelajaran matematika pada materi matriks.

2. Bagi siswa

Sebagai pengalaman baru bagi siswa dalam pembelajaran matematika untuk mencapai pembelajaran yang bermakna.

3. Bagi sekolah

Hasil penelitian ini diharapkan dapat dikembangkan di sekolah khususnya mata pelajaran matematika dan mata pelajaran lain.

4. Bagi peneliti

Diharapkan dapat melakukan penelitian lebih lanjut untuk mengembangkan bahan ajar menggunakan pendekatan saintifik untuk materi lain.

\section{DAFTAR PUSTAKA}

NCTM. (2000). Principles and Standards for Schools Mathematics. USA : Reston. V.A

Pitadjeng. (2005). Pembelajaran Matematika yang Menyenangkan. Semarang: Depdiknas Dirjen Dikti.

Rohani, A. (2005). Pengelolaan Pengajaran. Jakarta: Rineka Cipta.

Suhardjono. (2006). Penelitian Tindakan Kelas. Jakarta: Bumi Aksara.

Tandililing, E. (2011). Peningkatan Pemahaman dan Komunikasi Matematis Serta Kemandirian Belajar Siswa Sekolah Menengah atas Melalui Strategi PQ4R dan Bacaan Refutation Text (Doctoral Jurnal "Mosharafa", Volume 5, Nomor 2, Mei 2016 ISSN 20864280 
dissertation, Universitas Pendidikan Indonesia).

\section{RIWAYAT HIDUP PENULIS}

Siti Ramziah, M.Pd. Lahir di Palembang,

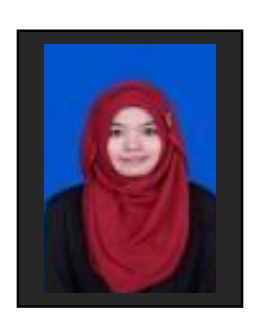

17 Februari 1988. Staf pengajar di SMAN 1 Banjar Margo Kab. Tulang Bawang Lampung. Studi S1 Pendidikan Matematika Universitas PGRI Palembang, lulus tahun 2009; dan S2 Pendidikan Matematika Universitas Sriwijaya, Palembang, lulus tahun 2012. 